\title{
Academic Achievement and Loneliness of Migrant Children in China: School Segregation and Segmented Assimilation
}

\author{
YAO LU AND HAO ZHOU
}

\begin{abstract}
China's rural-urban migration presents a significant educational challenge. This study uses theories of segmented assimilation and school segregation to measure the assimilation and well-being of migrant children who attend either Beijing's public schools or its informal migrant schools. Controlling for other factors, we find poorer achievement and greater loneliness among migrant children who are isolated in migrant schools than similar migrant students enrolled in regular urban public schools. We show there is little difference in learning outcome or loneliness between urban native children and migrant children who attend public schools. We further discuss similarities and differences between the experiences of migrant children in China and immigrant children in the United States.
\end{abstract}

Internal migration has been recognized as an integral feature of China's national economy and family life since the 1980s (Zhang and Song 2003). By the beginning of the twenty-first century, rural-to-urban migration had brought over 20 million migrant children to Chinese cities (Duan and Zhou 2001). Previous studies have found a substantial educational attainment gap in cities between rural migrant children and nonmigrant urban children (Guo 2002; CYRC 2006), but they have investigated migrant children as one homogeneous group. Moreover, past studies have mainly focused on migrant children's school enrollment. In this article, we account for the fact that migrant children have diversified in the most recent decade: some are able to attend urban public schools that used to admit only urban children while others are segregated into substandard migrant schools (Guo 2002). We then analyze the implications of this school segregation on children's academic performance and psychological well-being, especially their feelings of loneliness.

China's unique institutional arrangements limit migrants' ability to claim urban citizenship. This feature of internal migration distinguishes China from

\footnotetext{
The authors thank the anonymous reviewers and editors for their helpful comments. Data collection was supported by grants from the National Social Science Foundation of China (06CRK003), Beijing Municipal Social Science Foundation (05JC840019), and Beijing Municipal Natural Science Foundation (9072004). Yao Lu gratefully acknowledges support from NICHD (R03HD062691). Hao Zhou acknowledges support from the Urban China Research Network in the early stage of this research.
}

Received January 26, 2011; revised August 2, 2011; accepted January 25, 2012; electronically published October 9, 2012

Comparative Education Review, vol. 57, no. 1.

(C) 2012 by the Comparative and International Education Society. All rights reserved. $0010-4086 / 2013 / 5701-0002 \$ 10.00$ 
many other developing countries, where rural-to-urban migrants and their children often achieve upward mobility (Brockerhoff 1994). The institutional context of internal migration in China is more similar to international migration, especially undocumented immigration, in western societies (Roberts 1997). Thus, the extensive literature on children of immigrants in western countries, especially the United States, can inform studies of migrant children in China.

One relevant US stream of literature focuses on the impact of school environment on children. Specifically, school segregation of immigrant and minority children in the United States has adverse consequences for various aspects of child development (Rumberger and Palardy 2005). Another useful body of literature has developed around the theory of "segmented assimilation," which posits diverse processes and outcomes of assimilation of the second generation lead some groups to integrate to the mainstream while others languish in poverty (Portes and Zhou 1993). Can these theoretical frameworks — child development and segmented assimilation-be applied to migrant children in China? Given the substantial structural barriers that keep a large fraction of Chinese migrant children segregated in low-quality informal schools, we see school segregation as an important mechanism for differential assimilation experiences of Chinese migrant children. We expect that the consequences are similar to those predicted by segmented assimilation theory.

In this article, we examine the respective experiences of different groups of migrant children relative to native urban children. This analysis also addresses a lingering question of whether the observed disadvantages experienced by Chinese migrant children are due to their poor family background, or whether they are due to a bifurcated social institution that thwarts many migrants and their offspring. We use recent panel data on primary school children in Beijing (a primary migration destination in China) collected during 2006-7 to examine the gap in academic achievement and psychological well-being across various groups of children.

\section{Background: Migrant Children in China}

Economic reforms in China since the late 1970s have drawn over 220 million migrants from villages to cities (NBS 2011), and the rate of migration is anticipated only to increase (Zhang and Song 2003). Over time, Chinese migration has evolved from single-person to family movement. An increasing number of migrants have also started families in cities. According to the 2000 census, there were over 20 million migrant children in Chinese cities, and over 75 percent of them were of school age (Duan and Zhou 2001). In Beijing, the number was over 400,000 in the mid-2000s (Wang 2009). Although there are no up-to-date statistics on the overall scale of migrant children, assuming 
an increase at a similar rate to the total migrant population, the likely number of migrant children today is close to 30 million.

Despite the large stream of migrants, a long-standing bifurcated social system separating urban and rural Chinese (i.e., the household registration system, or $h u k o u^{1}$ ) has precluded peasant migrants from acquiring full citizenship in urban areas (Chan and Zhang 1999). Without a local urban hukou, rural migrants are excluded from many job openings and are forced into the undesirable and poorly paid jobs that are avoided by urban residents, such as construction and domestic services (Yang and Guo 1996). They also receive very limited social welfare services, such as housing, health care, and education for their children (Solinger 1999).

While large rural-urban disparities in income and infrastructures in developing settings often imply considerable benefits for migrants and their children (Brockerhoff 1994), accumulating evidence in China paints a rather pessimistic picture. One legacy of China's planned economy is that one's right to school enrollment is tied to one's place of household registration (Solinger 1999). As a result, migrant children were denied admission to urban schools until 1996, when the Ministry of Education mandated that local governments provide migrant children access to compulsory education. This policy marked the beginning of a series of regulations by the central government to improve the educational opportunities of migrant children. One important regulation was the Notice of Improving Education of Children of Rural Migrant Workers, enacted in 2005 and affirming, for the first time, that migrant children should receive free compulsory education.

Progress toward integration has not been commensurate with policy making, however. Many migrant children are admitted to urban public schools only if the schools have space for additional students, and only when migrant families pay a lump sum of temporary enrollment fees ( $\mathrm{Li}$ and $\mathrm{Li} 2010$ ). These fees usually total a few thousand yuan per year and can be as high as $¥ 30,000$ (Fleisher and Yang 2003). ${ }^{2}$ Such fees are up to six times what resident urban families pay for educational expenses, and they represent a financial burden for low-income migrants, who on average earned less than ¥1,000 per month in the late $1990 \mathrm{~s}$, around $¥ 1,500$ by the mid-2000s, and close to $¥ 1,700$ in 2010 (Meng and Zhang 2001; Ruan 2009; NBS 2011). Despite a series of government policies that endorse fee waivers for migrant children, school administrators often invent ingenious ways to charge admission fees (e.g., "donations") to circumvent the policies.

In addition to the monetary costs of schooling in urban areas for rural migrant children, social discrimination presents another barrier (CYRC

\footnotetext{
${ }^{1}$ Hukou divides agricultural (rural) and nonagricultural (urban) populations in China. Except under special circumstances, mainly the achievement of tertiary schooling, it is extremely difficult to change from agricultural to nonagricultural hukou (Wu and Treiman 2004).

${ }^{2}$ In the mid-2000s, ¥1 was roughly equivalent to US $\$ 0.125$. Nowadays, $¥ 1 \simeq$ US\$0.157.
} 
2006). Migrant children are frequent targets of prejudice, stereotyped as wild, lacking manners, and incompetent. It is common for migrant children to be asked to pass an exam before enrolling in public schools, whereas such exams are not enforced for urban children except in a few highly selective schools. Because of such costs and discrimination, many migrant children do not attend public schools. However, since the mid-1990s, a grassroots response within migrant communities has created informal migrant schools. By 2007, there were more than 300 such migrant schools in Beijing, enrolling over 170,000 children (Du 2006; Tao and Yang 2007). These schools are smallscale private schools run by migrant workers and charge lower fees of $¥ 300$ 600 per semester (Tao and Yang 2007). Although such schools help migrant children acquire basic education, their existence is precarious since they receive little public funding, despite policies urging local government to recognize and support migrant schools. Migrant schools often fail to meet the minimum standards set by local educational authorities, with problems ranging from poor facilities and overcrowded classes to a lack of qualified teachers and teaching materials (Kwong 2004).

Previous studies have examined the school attendance of migrant children, documenting their low rates of attendance and graduation (Guo 2002; $\mathrm{Lu} 2007$ ). The low attainment of migrant children is usually attributed to their rural origin and poor family socioeconomic background (CYRC 2006). Some suggest that migrant children's urban schooling opportunities are even worse than their rural counterparts (Liang and Chen 2004). In a four-city study of Beijing, Shenzhen, Shaoxing, and Xianyang, about half of the migrant children who attended school did so in public schools (Zou et al. 2005), but this number has gradually increased over time. In recent years in Beijing, according to government statistics, the proportion of migrant children enrolling in public school grew to about 60 percent (Tao and Yang 2007; Wang 2009).

Although urban public schools offer better educational resources and opportunities than migrant schools, there is often a concern that public schools are not well suited to migrant children because of discrimination and unfair treatment from teachers and peer native students. With respect to other dimensions of well-being, such as school performance and psychological health, the experiences of migrant children are receiving increasing attention. A growing body of research underscores the challenges facing migrant children in terms of academic achievement and psychological health in such major migrant destinations as Guangdong, Beijing, and Chongqing (Lin and Weng 2004; Sun 2007; Xiao and Feng 2008; Zhou 2008).

While previous investigations offer valuable insights, they have been based largely on anecdotal evidence or qualitative studies. Previous survey-based studies have often collected data only on migrant children, failing to sample a comparison group of nonmigrant children and making it impossible to 
assess the relative status of migrant children to urban children. Moreover, earlier studies have rarely evaluated the respective experiences of different groups of migrant children. In addition, almost no studies used longitudinal data that would allow for a more rigorous analysis of the well-being of migrant children. Our research seeks to bridge these gaps and update our understanding through studying migrant children in Beijing.

\section{Segmented Assimilation and School Segregation for Chinese Migrant Children}

From a broader comparative perspective, internal migration in China is unique due to the institutionalized internal division of the Chinese population enforced by the hukou system. At the same time, Chinese internal migration shares significant structural elements with migrant experiences in other societies, where these elements often intersect with race, ethnicity, and citizenship status. In this respect, the extensive literature on children of immigrants in western countries, especially the United States, can inform studies of migrant children in China.

One major framework developed to understand the well-being of immigrant children is the segmented assimilation perspective (Portes and Zhou 1993). Rather than expecting uniform experiences of adaptation, this perspective predicts divergent outcomes for immigrant children, depending on the human capital, social capital, and other resources of their immigrant parents and communities. Some children would achieve upward assimilation as a result of their parents' high socioeconomic status and favorable context of reception, eventually integrating into the white middle-class mainstream. In contrast, children whose immigrant parents lack resources and who are exposed to inner-city neighborhoods would experience downward assimilation to the underclass, stagnant at the bottom of society. A third group may combine upward mobility with traditional cultural values. Such selective acculturation often turns out to be an advantage.

Nevertheless, much empirical work in the United States finds little evidence of downward assimilation, even for children of low-income immigrant parents (Foner 2005). While all three types of assimilation occur, downward assimilation is the least likely (Kasinitz et al. 2002). The bulk of immigrant children fare better in socioeconomic terms than their parents' generation and often reach parity with, and exceed, their native-born peers, after adjusting for a wide range of background characteristics. This pattern leads to a refined perspective that posits that most of the contemporary second generation would experience gradually increasing social integration (Alba and Nee 2003). These observations are attributed to many legal, social, and economic policies that grant the children of immigrants protections, opportunities, and even benefits (Farley and Alba 2002). Although, on average, immigrant families tend to be worse off socioeconomically than native families (50 percent vs. 33 percent below twice the poverty level; Capps et al. 2003), 
US civil rights legislation and affirmative action programs have largely afforded immigrant children opportunities for advancement in mainstream institutions and protected them from downward mobility. With respect to education, by law, immigrant students are entitled to free public education from kindergarten through grade 12, even if they are undocumented children. Hence, the opportunities described above also apply to children of undocumented immigrants, though they tend to have poorer outcomes than do children of legal immigrants (Fernandez-Kelly and Curran 2001). In comparison, native minority children tend to have the poorest outcomes.

A range of factors has been studied to understand the well-being of immigrant and minority children and variations within these groups. One set of factors concerns school context, including both the structural (e.g., quality, curriculum, composition) and social resources (e.g., collective responsibility, peer and student-teacher relationships) of schools (Hao and Pong 2008). Some groups of immigrant children and a large fraction of minority children live in inner-city neighborhoods with poor and segregated schools (Rumberger and Palardy 2005). An extensive literature connects the widespread school segregation in the United States to inequality in educational attainment, suggesting that students in segregated schools tend to perform less well than other children and are more likely to drop out of school and engage in risky behaviors (Wells and Crain 1994).

School segregation is strongly associated with socioeconomic segregation, with predominantly minority schools commonly struggling with poverty and limited resources. Segregated schools, for example, are much more likely to have overcrowded classrooms, employ poorly performing teachers, and provide a less nurturing atmosphere (Darling-Hammond and Post 2000). Independent of the socioeconomic environment, racial and ethnic composition within schools also has important impacts on students' outcomes. For ethnic minority children, attending mainstream education institutions-that is, desegregated schools with a large proportion of white students-is associated with higher achievement, higher self-worth, and better social competence (Postmes and Branscombe 2002). Students in desegregated settings also tend to report fewer incidents of racial discrimination. These results have prompted scholars to advocate for the integration of minority and nonminority students in the school setting (Schofield 1995).

It is worth noting that school segregation in the United States toward immigrant children is much less evident than that between whites and nonwhite children, or between poor and middle-income students (Ellen et al. 2002). There are some variations by particular immigrant groups, as shown in a study on New York City (Ellen et al. 2002). For instance, students from the former Soviet Union often attend high-quality schools with students mostly from middle-income and white families. In contrast, Dominican immigrant children are commonly found in segregated schools attended almost 
exclusively by poor black or Hispanic students. Despite these variations, overall there is little evidence that immigrant children as a whole experience sizable segregation or sizable effects of segregation.

\section{The Case of Chinese Migrant Children}

The theoretical perspectives discussed above are relevant to understanding Chinese migrant children, but they need to be adapted to suit the Chinese setting in which migrants face a different institutional context. Segmented assimilation theory stresses the interaction between assimilation and social contexts, especially family and community resources, but does not explicitly outline the role of school segregation in assimilation outcomes. This omission may exist partly because in the United States, school segregation mostly intersects with race as opposed to immigration status. In China, however, school segregation can operate as a crucial mechanism for the process of assimilation of migrant children given the substantial structural barriers these children face. While some migrant children are able to enter mainstream education institutions (public schools), many have endured significant segregation in informal migrant schools.

In the present study, we integrate segmented assimilation theory with the literature on school segregation to examine the outcomes of different groups of migrant children. On the basis of the consistent finding of an adverse impact of school segregation on children in the United States, we expect Chinese migrant children in public schools to benefit from attending desegregated education institutions. Such schools offer superior connections to the mainstream, better educational resources, and possibly a lower level of discrimination-characteristics that can launch migrant children on a path toward assimilation. In contrast, segregation of migrant children in migrant schools tends to increase their contact with an unfavorable school environment and a disadvantaged population, subsequently slowing or even halting the assimilation process.

These different paths point to distinct assimilation outcomes of Chinese migration children, similar to the scenarios of upward and downward assimilation depicted in the segmented assimilation theory. The theory assumes, however, that the host society is divided into different segments-a mainstream population and a clearly identifiable underclass (i.e., inner-city racial minorities) - and then investigates into which segment immigrants may integrate. This condition needs to be modified in the Chinese case, where there is no visible underclass (i.e., an underclass unique to one particular social group) in cities and the native urban children are much less heterogeneous than native US children. The main issue for Chinese migrant children is whether they would assimilate into the general mainstream population, namely, with relatively homogeneous urban children, or whether they would fail to assimilate and succumb to the bottom of the urban hierarchy. If the 
integration of migrant children is found to take different paths, we consider it as segmented, falling within the broader scope of upward and downward assimilation. The case of selective assimilation is less relevant in the context of internal migration in China and is thus not addressed in this article.

Specifically, to examine the role of school segregation in the assimilation process of migrant children in China, we compare the well-being of different groups of migrant children and urban children, while adjusting for a rich set of family background and parental characteristics. We focus on two domains of child development: academic performance and psychological health. The former is a crucial determinant of ultimate educational attainment and human capital, while the latter is an integral component of overall health. Both dimensions can carry long-term consequences for child development and for transitions to adolescence and adulthood. We hypothesize that there are substantial differences between the two groups of migrant children relative to urban children, which translate into divergent patterns of assimilation. That is, migrant children in public schools tend to do well and fare relatively similarly to urban children, while those segregated in migrant schools tend to endure large disadvantages compared to not only urban children but also to migrant children in desegregated schools.

\section{Data and Methods}

The data used in this study are from the Panel Study of the Development of Migrant Children, directed by Hao Zhou (www.psdmc.net). The sampling frame included public and migrant elementary schools in a Beijing district where most migrants congregate. The survey was approved by the Beijing Municipal Education Commission, which provided a list of public primary schools and migrant primary schools with information on the number of classes and the average class size by grade level. The data were collected using stratified clustering sampling. First, all third-grade classes were stratified by school type (public and migrant schools) and by the average class size (above and below the average class size across all schools, which was 32). Within each stratum, classes across schools were ordered and selected with probability proportional to size, resulting in 19 third-grade classes from 12 public schools and seven migrant schools. In each selected school, a class in the fifth grade was also selected to allow for comparison of children at different grade levels. The fifth-grade class was randomly chosen in selected schools using random numbers. All students in the sampled classes were asked to participate. The baseline survey was completed in November 2006, with two follow-up surveys in May 2007 and November 2007. The sample size was 1,259 in the first wave. About 20 percent of children were lost to follow-up across all waves due to dropout, relocation, or school transfer. The attrition rate was higher for children in migrant schools (31 percent), consistent with previous studies showing that in migrant schools around one-third of students transfer or 
drop out annually (CYRC 2006). We carried out sensitivity analysis to examine whether attrition was systematically related to children's prior academic and psychological well-being measured in the first wave, and we found no significant relationship.

Two sets of questionnaires were administered in each wave, one for the children and one for their parents. In each sampled class, two survey supervisors were present to answer questions while students filled out the questionnaires. Parent questionnaires were brought home by the students, filled out by parents, and returned to school. This strategy yielded a high response rate, 99 percent for the child survey and 91 percent for the parent survey. The child questionnaire recorded information on children's demographics, living environment, parent-children relations, academic achievement, and psychological health. The parent questionnaire included information on parental demographics and socioeconomic status, family life and parenting, and migration status.

\section{Measures}

We study children's academic performance (using math and Chineselanguage test scores) and their psychological well-being using a series of questions designed to measure feelings of loneliness. The math and Chineselanguage tests were developed by education researchers who specialized in primary school education, and they were based on the curriculum designed by the State Education Commission at corresponding grade levels. The tests varied by grade level and across waves to accommodate different curriculum requirements for each semester. The tests were pretested and revised before being used in the survey. The math and language test scores were studied separately because they tend to capture different dimensions of academic abilities. We added the correct answers to create a total score (50 points for each test), with higher values indicating better performance. The absolute values of total scores were then converted to normalized percentile scores to be included in the regression analysis.

Loneliness is an important aspect of psychological distress in childhood and adolescence (Rubin et al. 2002). We used the child self-evaluation of loneliness constructed by Asher and colleagues (1984), which has been adapted in the Chinese context (Chen et al. 2000). The scale included 16 questions (e.g., "I feel alone," and "I have nobody to talk to"), each ranging from 1 to 5 (from "not true at all" to "always true"). Following procedures outlined by Asher et al. (1984), we added children's responses to the 16 selfstatements in this scale, with higher scores indicating greater feelings of loneliness. The internal reliability of this scale is 0.9 over time.

We included independent variables at varying levels, as summarized in table 1 . The crucial predictor is a three-category variable that differentiates urban children (all in public schools), migrant children in public schools, 
LU AND ZHOU

TABLE 1

Descriptive Statistics by Migration and School Status, First Wave, 2006

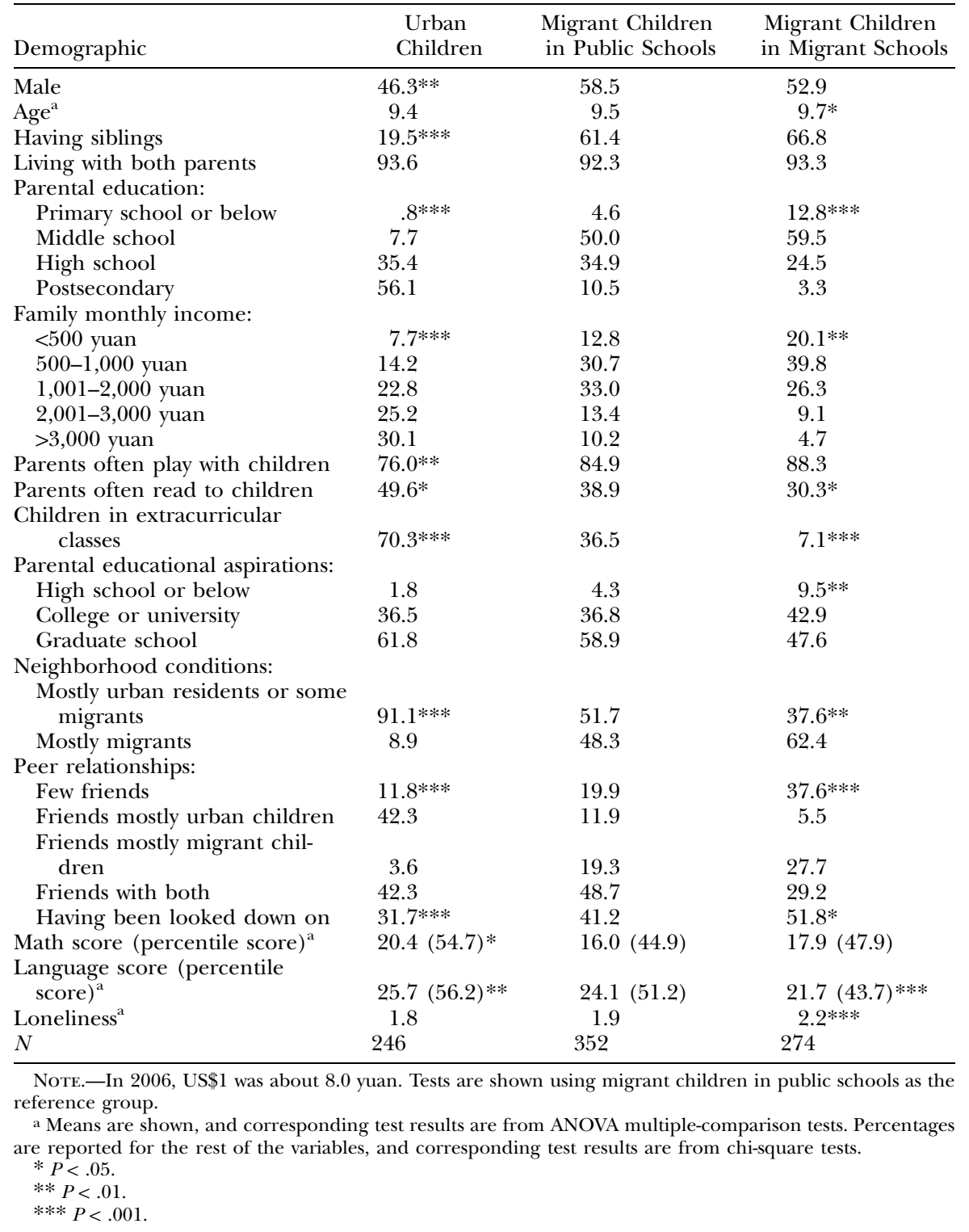

and migrant children in migrant schools. Because migration is an adaptive process, we examined the pattern of assimilation over time of migrant children by further distinguishing migrant children by duration of residence in Beijing. We used 5 years, the median duration of residence, as the cutoff.

We controlled for child- and family-level factors that may explain the gap in well-being across different groups of children. These factors also helped adjust for possible selection of children into different types of schools. En- 
rolling children in public schools rather than migrant schools may reflect an advantaged family background or greater willingness of parents to invest in children, both predisposing children to better outcomes. Adjusting for these factors permitted a more accurate estimate of the cross-group differences. The child-level characteristics included gender, age, and the number of siblings (an indicator of familial resource competition). To take account of family socioeconomic status, we used parental education and income. To measure parental input, we used family structure (two-parent vs. single-parent) and two dichotomous variables indicating whether the parents often played with and read to children. We included another important determinant of academic performance: whether parents enrolled children in extracurricular classes, which is shown to boost academic achievement in China. To adjust more effectively for the potential selection of migrant children into public and migrant schools, we included a discrete variable of parents' educational aspirations across all models.

We also evaluated children's peer relations, perceived discrimination, and community environment as correlates of child well-being (Aneshensel 1992; Laursen 1995). For neighborhood conditions, we used a dichotomous measure indicating whether the child lived in a community with a high concentration of migrants. We also included an indicator of children's perceived discrimination, measured by whether the child reported that he or she has been looked down upon. Children's peer relationships were measured by a discrete variable distinguishing whether a child's friends were mostly urban children, mostly migrant children, or both.

\section{Statistical Methods}

We used linear regression models, first comparing the raw difference across the three groups of children and then sequentially controlling for children's demographics, family background, parental input, and social environment. We focused on examining whether the differences between children remain after adjusting for these factors. We pooled all three waves of data to estimate random effect (RE) models. The RE models are suitable for longitudinal data with multiple observations over time per child, by accounting for the dependence of these observations in the variance-covariance structure (Raudenbush and Bryk 2002). Without these adjustments, the standard regression assumption of independence would be violated. This approach allows for exploiting the richness of data over the course of children's development, which leads to more efficient estimates.

To minimize reverse causation (children's well-being may in turn affect factors such as parental involvement and children's social experiences), we used lagged measures of the predictors (one-wave lag of the outcome variables). We also included a lagged measure of the outcome-children's academic performance or psychological health-to capture prior child well- 
being. The lagged dependent variable approach helped address possible selection bias to the extent preexisting differences between children are captured in the lagged measure. Letting $i$ index waves and $j$ index children, a linear random-intercept model is formulated as follows:

$$
y_{i j}=\beta_{0}+\zeta_{j}+\beta_{1} X_{(i-1) j}+\beta_{2} y_{(i-1) j}+\varepsilon_{i j}
$$

where $\beta_{0}$ is the main intercept; $\zeta_{j}$ is a random effect for each child, which is assumed to be normally distributed with mean zero and variance $\psi$ in the population; $X_{(i-1) j}$ is a vector of time-lagged predictors; $\beta_{1}$ is a vector of the coefficients associated with these covariates; $y_{i j}$ and $y_{(i-1) j}$ are, respectively, the outcome and the lagged measure of child well-being; and $\varepsilon_{i j}$ is the error term for each observation. The final analysis is based on 872 children, after deleting less than 10 percent of cases with any missing data.

\section{Descriptive Statistics}

Table 1 shows substantial differences between migrant children and urban children, and between the two groups of migrant children, with children in migrant schools being disadvantaged in many aspects. For each variable, we carried out $t$-tests or chi-square tests to examine whether the difference between urban children and migrant children in public schools and the difference between the two groups of migrant children are statistically significant. As for demographics, more than 50 percent of migrant children were males, compared to 46 percent of urban children. Both groups of migrant children were more likely to have siblings because the one-child policy is less strictly enforced in rural areas where migrants came from. Most children lived with both parents. With respect to family background, over 90 percent of urban children's parents had at least some high school education. By contrast, over half of the parents of migrant children had less than middle school education. Likewise, migrants earned significantly less than urban residents. Both the educational and income disparities were especially salient for migrant children in migrant schools.

Turning to parental input, although urban children reported less play time with their parents, they reported more reading time. This finding may be because urban parents tended to emphasize academic input. It may also reflect the limited human capital of migrant workers, which hindered their ability to assist with children's formal learning. In addition, urban children were much more likely to enroll in extracurricular classes, which often required substantial fees, followed by migrant children in public schools. There also was a noticeable difference in parental educational aspirations: urban parents had the highest educational expectations for their children, slightly more than migrant parents sending children to public schools. Migrant parents sending children to migrant schools had the lowest expectations.

For the two groups of migrant children (those in public schools and those 
in migrant schools), 48 percent and 62 percent, respectively, lived in migrant enclaves, making their social integration particularly difficult. This geographical segregation was accompanied by social discrimination against migrant children. A significantly higher number of migrant children, especially those in migrant schools, reported having this negative social experience. Not surprisingly, due to the overwhelming prejudice attached to rural origin and the segregated environment facing migrant children, many of these children had limited interactions with urban children. This situation appeared to be the worst for those children isolated in migrant schools: almost 40 percent of them had no or few friends, and only slightly over 30 percent interacted with urban children.

While migrant-local gaps are expected, differences in social experiences between the two groups of migrant children suggest that concern about migrant children suffering greater discrimination in public schools than in migrant schools should be revisited. While migrant children in public schools reported significantly higher levels of discrimination than urban children, they fared better than their counterparts in migrant schools. Attending migrant schools may reduce day-to-day conflicts between urban children and migrant children, but it also reduces migrant children's opportunities for interactions with their local peers, which are essential for minimizing misunderstandings and prejudices. This segregation could subsequently slow or even stall the process of incorporation.

As for academic performance, migrant children did more poorly in both math and language tests than urban children. They were also more likely to feel lonely than local children. For three groups of students we examined trends over time in language percentile scores and the loneliness scale (see the left and right sides, respectively, of fig. 1). Math scores are not shown as they revealed similar patterns to language scores. The gap in language scores between urban children and migrant children was large. Children in migrant schools performed most poorly across all waves, and the gap remained substantial over time (the gap even appeared to be larger in wave 3 than in wave 1). Migrant children in public schools fared much better than their peers in migrant schools and seemed to catch up gradually with urban children, although there remained a small gap by wave 3 .

Children in migrant schools were the most disadvantaged group when it came to psychological well-being, as seen from their higher loneliness score. Their gap with the other two groups was huge. Over time, while migrant children in public schools became better integrated and rapidly closed the gap with urban children, those in migrant schools did not experience significant improvement in psychological outcomes. These results seemed to portray a picture of segmented assimilation among Chinese migrant children in China: when offered opportunities for incorporation (i.e., attending public 

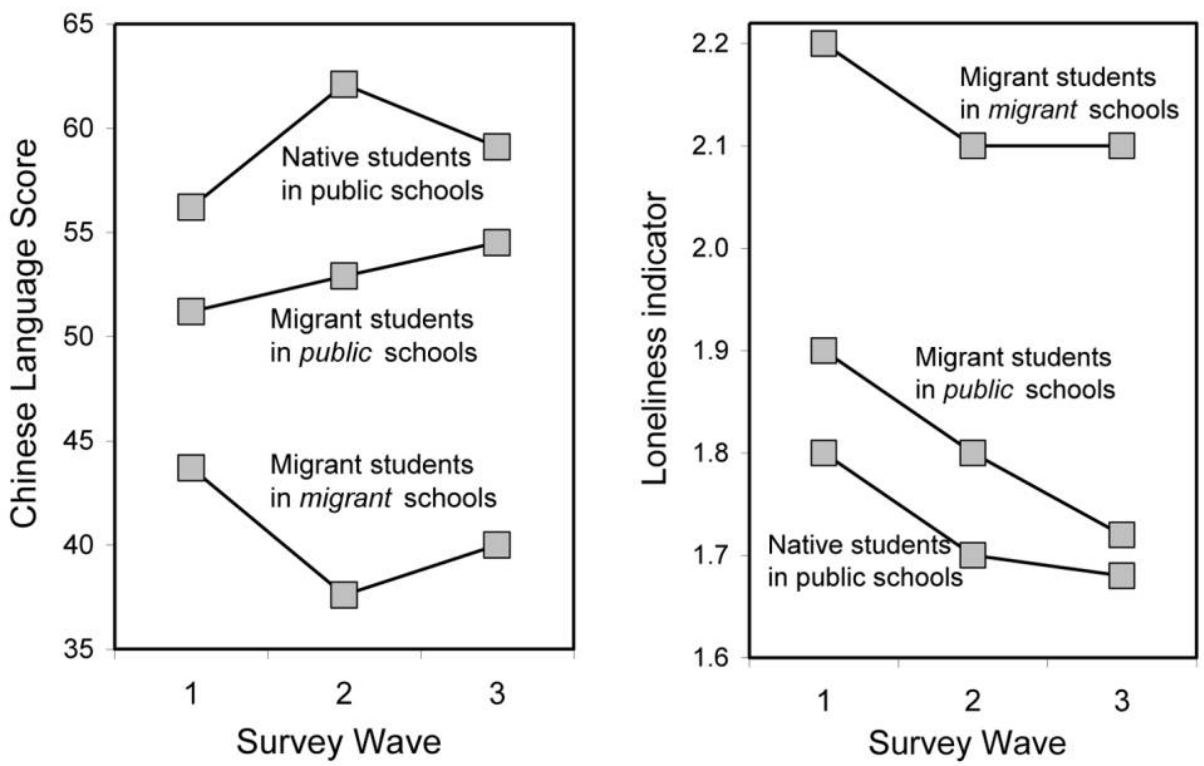

Fig. 1.-Patterns of Chinese language achievement and indicators of loneliness for native and migrant students in public and special migrant schools in Beijing.

schools), a group of migrant children were able to improve their academic and psychological well-being.

\section{Regression Results}

We next discuss regression analysis that adjusts for a wide range of factors. We performed a series of models, controlling first for demographic characteristics (model 1), then for family socioeconomic background (model 2), parental input (model 3), and finally for social environment (model 4). For each model, we also explicitly compared the two groups of migration children, as shown at the bottom of each table.

With respect to math test scores (table 2), there was little difference across the three groups of children. Although migrant children appeared to perform more poorly than urban children (model 1), this gap disappeared once we adjusted for the background factors that may explain the difference. There was also no significant difference between the two groups of migrant children. Models 5 and 6 further explored the gender interaction and the difference by migrants' duration of stay. We found no clear evidence of either gender or duration differences. With respect to other factors, parental education and educational aspirations were positively associated with math test scores but not other family background variables. 
TABLE 2

Random Effect Models Predicting Children’s Math Test Scores, 2006-7 $(N=872)$

\begin{tabular}{|c|c|c|c|c|c|c|}
\hline & \multicolumn{6}{|c|}{ Model } \\
\hline & 1 & 2 & 3 & 4 & 5 & 6 \\
\hline \multicolumn{7}{|l|}{ Migration and school status (ref. urban children): } \\
\hline Migrant children in public schools & $\begin{aligned}-.132 \\
(.074)\end{aligned}$ & $\begin{array}{l}.092 \\
(.081)\end{array}$ & $\begin{array}{l}.073 \\
(.08)\end{array}$ & $\begin{array}{l}.073 \\
(.085)\end{array}$ & $\begin{array}{l}.049 \\
(.11)\end{array}$ & \\
\hline Migrant children in migrant schools & $\begin{array}{c}-.183^{*} \\
(.083)\end{array}$ & $\begin{array}{l}.132^{+} \\
(.077)\end{array}$ & $\begin{array}{l}.107 \\
(.093)\end{array}$ & $\begin{array}{l}.156 \\
(.102)\end{array}$ & $\begin{array}{l}.028 \\
(.126)\end{array}$ & \\
\hline \multicolumn{7}{|l|}{ Interaction by gender: } \\
\hline Migrant children in public schools, ${ }^{*}$ male & & & & & $\begin{array}{l}.094 \\
(.13)\end{array}$ & \\
\hline Migrant children in migrant schools, ${ }^{*}$ male & & & & & $\begin{array}{l}.207 \\
(.144)\end{array}$ & \\
\hline \multicolumn{7}{|l|}{ By length (ref. urban children): } \\
\hline Migrant children in public schools ( $\leq 4$ years) & & & & & & $\begin{array}{l}.206 \\
(.155)\end{array}$ \\
\hline Migrant children in public schools ( $\geq 5$ years) & & & & & & $\begin{array}{l}.061 \\
(.093)\end{array}$ \\
\hline Migrant children in migrant schools ( $\leq 4$ years) & & & & & & $\begin{array}{l}.202 \\
(.118)\end{array}$ \\
\hline Migrant children in migrant schools ( $\geq 5$ years) & & & & & & $\begin{array}{l}.176 \\
(.123)\end{array}$ \\
\hline Male & $\begin{aligned}-.008 \\
(.058)\end{aligned}$ & $\begin{array}{l}.01 \\
(.057)\end{array}$ & $\begin{array}{l}.014 \\
(.057)\end{array}$ & $\begin{array}{l}.016 \\
(.057)\end{array}$ & $\begin{array}{l}-.155 \\
(.105)\end{array}$ & $\begin{array}{l}.028 \\
(.06)\end{array}$ \\
\hline 5th grade (ref. 3rd grade) & $\begin{array}{r}-.058 \\
(058)\end{array}$ & $\begin{array}{c}-.063 \\
(.057)\end{array}$ & $\begin{array}{c}-.067 \\
(.057)\end{array}$ & $\begin{array}{r}-.115^{*} \\
(.058)\end{array}$ & $\begin{array}{c}-.108 \\
(.058)\end{array}$ & $\begin{array}{c}-.015 \\
(.062)\end{array}$ \\
\hline Having siblings & $\begin{array}{c}-.140 * \\
(.063)\end{array}$ & $\begin{array}{c}-.066 \\
(.064)\end{array}$ & $\begin{array}{c}-.054 \\
(.063)\end{array}$ & $\begin{array}{c}-.058 \\
(.064)\end{array}$ & $\begin{array}{c}-.035 \\
(.065)\end{array}$ & $\begin{array}{c}-.081 \\
(.068)\end{array}$ \\
\hline Not living with both parents & & $\begin{array}{c}-.206 \\
(.114)\end{array}$ & $\begin{array}{c}-.202 \\
(.113)\end{array}$ & $\begin{array}{c}-.119 \\
(.115)\end{array}$ & $\begin{array}{c}-.125 \\
(.115)\end{array}$ & $\begin{array}{c}-.065 \\
(.12)\end{array}$ \\
\hline
\end{tabular}


TABLE 2 (Continued)

\begin{tabular}{|c|c|c|c|c|c|c|}
\hline & \multicolumn{6}{|c|}{ Model } \\
\hline & 1 & 2 & 3 & 4 & 5 & 6 \\
\hline \multicolumn{7}{|c|}{ Parental education (ref. primary school or below): } \\
\hline Middle school & & $\begin{array}{c}-.077 \\
(.135)\end{array}$ & $\begin{array}{c}-.098 \\
(.134)\end{array}$ & $\begin{array}{c}-.098 \\
(.134)\end{array}$ & $\begin{array}{c}-.103 \\
(.134)\end{array}$ & $\begin{array}{c}-.121 \\
(.145)\end{array}$ \\
\hline High school & & $\begin{array}{l}.038 \\
(.139)\end{array}$ & $\begin{array}{c}-.022 \\
(.139)\end{array}$ & $\begin{array}{l}.014 \\
(.14)\end{array}$ & $\begin{array}{l}.008 \\
(.14)\end{array}$ & $\begin{array}{c}-.031 \\
(.15)\end{array}$ \\
\hline Postsecondary & & $\begin{array}{l}.454^{* *} \\
(.157)\end{array}$ & $\begin{array}{l}.377^{*} \\
(.157)\end{array}$ & $\begin{array}{l}.403^{*} \\
(.158)\end{array}$ & $\begin{array}{l}.399 * \\
(.159)\end{array}$ & $\begin{array}{l}.362^{*} \\
(.169)\end{array}$ \\
\hline \multicolumn{7}{|c|}{ Family monthly income (ref. $<500$ yuan): } \\
\hline $500-1000$ yuan & & $\begin{array}{c}-.079 \\
(.098)\end{array}$ & $\begin{array}{c}-.083 \\
(.098)\end{array}$ & $\begin{array}{c}-.043 \\
(.099)\end{array}$ & $\begin{array}{c}-.039 \\
(.099)\end{array}$ & $\begin{array}{c}-.026 \\
(.105)\end{array}$ \\
\hline 1001-2000 yuan & & $\begin{array}{c}.011 \\
(.098)\end{array}$ & $\begin{array}{l}.009 \\
(.098)\end{array}$ & $\begin{array}{l}.003 \\
(.099)\end{array}$ & $\begin{array}{l}.009 \\
(.099)\end{array}$ & $\begin{array}{c}-.014 \\
(.105)\end{array}$ \\
\hline 2001-3000 yuan & & $\begin{array}{l}.031 \\
(.112)\end{array}$ & $\begin{array}{l}.02 \\
(.112)\end{array}$ & $\begin{array}{l}.037 \\
(.113)\end{array}$ & $\begin{array}{l}.033 \\
(.113)\end{array}$ & $\begin{array}{l}.013 \\
(.119)\end{array}$ \\
\hline$>3000$ yuan & & $\begin{array}{l}.102 \\
(.121)\end{array}$ & $\begin{array}{l}.077 \\
(.12)\end{array}$ & $\begin{array}{l}.089 \\
(.121)\end{array}$ & $\begin{array}{l}.079 \\
(.121)\end{array}$ & $\begin{array}{l}.06 \\
(.128)\end{array}$ \\
\hline Parents often play with children & & & $\begin{array}{l}.089 \\
(.078)\end{array}$ & $\begin{array}{l}.077 \\
(.079)\end{array}$ & $\begin{array}{l}.073 \\
(.079)\end{array}$ & $\begin{array}{c}-.057 \\
(.083)\end{array}$ \\
\hline Parents often read to children & & & $\begin{array}{l}.064 \\
(.061)\end{array}$ & $\begin{array}{l}.069 \\
(.062)\end{array}$ & $\begin{array}{l}.074 \\
(.062)\end{array}$ & $\begin{array}{c}-.083 \\
(.065)\end{array}$ \\
\hline Children in extracurricular classes & & & $\begin{array}{l}.059 \\
(.057)\end{array}$ & $\begin{array}{l}.072 \\
(.058)\end{array}$ & $\begin{array}{l}.071 \\
(.058)\end{array}$ & $\begin{array}{l}.064 \\
(.061)\end{array}$ \\
\hline \multicolumn{7}{|c|}{ Parental educational aspirations (ref. high school or below): } \\
\hline College or university & & & $\begin{array}{c}.251 \\
(.136)\end{array}$ & $\begin{array}{c}.283^{*} \\
(.138)\end{array}$ & $\begin{array}{c}.305^{*} \\
(.138)\end{array}$ & $\begin{array}{l}.221 \\
(.149)\end{array}$ \\
\hline Graduate school & & & $\begin{array}{l}.428^{* *} \\
(.135)\end{array}$ & $\begin{array}{l}.450^{* * *} \\
(.138)\end{array}$ & $\begin{array}{l}.468^{* * * *} \\
(.138)\end{array}$ & $\begin{array}{l}.394^{* *} \\
(.149)\end{array}$ \\
\hline \multicolumn{7}{|l|}{ Peer relationships (ref. few friends): } \\
\hline Friends mostly urban children & & & & $\begin{array}{l}.148 \\
(.113)\end{array}$ & $\begin{array}{l}.135 \\
(.113)\end{array}$ & $\begin{array}{l}.15 \\
(.116)\end{array}$ \\
\hline Friends mostly migrant children & & & & $\begin{array}{l}.059 \\
(.106)\end{array}$ & $\begin{array}{l}.074 \\
(.106)\end{array}$ & $\begin{array}{l}.11 \\
(.11)\end{array}$ \\
\hline Friends with both & & & & $\begin{array}{l}.260 * * \\
(.097)\end{array}$ & $\begin{array}{l}.259 * * \\
(.096)\end{array}$ & $\begin{array}{l}.240^{*} \\
(.099)\end{array}$ \\
\hline
\end{tabular}


Neighborhood conditions (ref. mostly urban residents or some migrants)

Mostly migrants

Wave 3 (ref. wave 2)

Lagged test score

Constant

Migrant children in migrant schools

(Ref. migrant children in public schools)

Migrant children in migrant schools,* male

$\begin{array}{cccccc} & & & -.099 & -.019 & -.045 \\ .208^{* * *} & .204^{* * *} & .186^{* *} & (.065) & (.058) & (.062) \\ -0.055 & -.055 & -.057 & -.069 & .118 & .122 \\ .279 * * * & .366^{* * *} & .346^{* * *} & .333^{* * *} & -.069 & -.074 \\ -.025 & -.028 & -.028 & -.029 & -.029 & -.0331^{* * *} \\ -.062 & -.345^{*} & -.554^{*} & -.710^{* *} & -.755^{* *} & -.736^{* * *} \\ -.074 & -.168 & -.217 & -.237 & -.233 & -.247 \\ & & & & & \\ -.051 & .04 & .035 & .083 & -.021 & \\ (.071) & (.072) & (.071) & (.074) & (.105) & \\ & & & & .113 & \\ & & & & (.139) & -.145 \\ & & & & & (.105) \\ & & & & & -.004 \\ & & & & & (.021) \\ & & & & & (.030)\end{array}$

(Ref. migrant children in public schools $\leq 4$ years)

Migrant children in public schools $\geq 5$ years

e Migrant children in migrant schools ( $\leq 4$ years)

Migrant children in migrant schools ( $\geq 5$ years)

$-.030$

NoTE.-Standard errors are in parentheses. At the bottom of the table, specific comparisons between the two groups of migrant children are presented. Ref. $=$ reference.

$+P<.10$.
$+P<.05$

$* P<.05$. 
Results of the language test scores showed markedly different patterns (table 3). These findings may be explained by earlier work that suggested that language ability largely hinges on socioeconomic factors, especially parental and school input, whereas math achievement is also determined by innate abilities and biological differences (McClearn et al. 1997; Plomin et al. 1997). Language achievement substantially favored urban children, followed by migrant children in public schools, with migrant-school children at the bottom. After controlling for family-level factors and social environment (models 2-4), the differences diminished, especially for migrant children at public schools. These children even seemed to outperform urban children slightly, but this difference lacked statistical significance. Nevertheless, the difficulties facing children in migrant schools remained substantial. These children performed worse in Chinese compared not only to urban children but also to their counterparts attending public schools. As shown at the bottom of the table, the gap between the two groups of migrant children was large and highly significant. Taken together, these results suggest that while poor family background, inadequate parental input, and negative social experiences of migrant children contributed to their lower academic performance, the structural barriers that relegated many of them to segregated school with substandard education also presented a crucial impediment to their academic achievement.

The gender difference was insignificant (model 5), suggesting that the gap existed for both boys and girls. In addition, the gaps between migrant children in migrant schools and in public schools, and between migrant and urban children, continued to be substantial regardless of migrant children's length of stay in Beijing (model 6). Although children in migrant schools underwent slight improvement over the course of their residence in cities, the change was insignificant. Segregating migrant children in migrant schools has thus limited their chances for achieving academic assimilation.

Other important factors of children's academic performance included parental education and family income. Parental input was not significantly associated with school achievement once family background factors were adjusted, but parental aspirations were among the most critical determinants of children's educational outcomes. Children's negative social experiences also seemed to deter academic achievement, but these differences generally lacked statistical significance. We would like to point out that these independent variables should be interpreted with caution because the relatively small sample size may make the estimates of the large set of predictors quite unstable.

Turning to psychological health (table 4), children in migrant schools were most likely to suffer from loneliness. This finding was partly explained by their disadvantaged family living environment. The large reduction of the coefficient from model 3 to model 4 (almost 40 percent) suggested that the 
TABLE 3

Random Effect Models Predicting Children's Chinese Language Test Scores, 2006-7 $(N=872)$

\begin{tabular}{|c|c|c|c|c|c|c|}
\hline & \multicolumn{6}{|c|}{ Model } \\
\hline & 1 & 2 & 3 & 4 & 5 & 6 \\
\hline \multicolumn{7}{|l|}{ Migration and school status (ref. urban children): } \\
\hline Migrant children in public schools & $\begin{array}{r}-.141 * \\
(.064)\end{array}$ & $\begin{array}{l}.047 \\
(.069)\end{array}$ & $\begin{array}{l}.036 \\
(.069)\end{array}$ & $\begin{array}{l}.050 \\
(.073)\end{array}$ & $\begin{array}{l}.012 \\
(.097)\end{array}$ & \\
\hline Migrant children in migrant schools & $\begin{array}{l}-.603 * * * \\
(.070)\end{array}$ & $\begin{array}{l}-.362 * * * \\
(.080)\end{array}$ & $\begin{array}{l}-.343 * * * \\
(.080)\end{array}$ & $\begin{array}{l}-.321 * * * \\
(.087)\end{array}$ & $\begin{array}{l}-.346 * * \\
(.110)\end{array}$ & \\
\hline \multicolumn{7}{|l|}{ Interaction by gender: } \\
\hline Migrant children in public schools, ${ }^{*}$ male & & & & & $\begin{array}{l}.073 \\
(.119)\end{array}$ & \\
\hline Migrant children in migrant schools,* male & & & & & .050 & \\
\hline \multicolumn{7}{|l|}{ By length (ref. urban children): } \\
\hline Migrant children in public schools ( $\leq 4$ years) & & & & & & $\begin{array}{l}.104 \\
(.099)\end{array}$ \\
\hline Migrant children in public schools ( $\geq 5$ years) & & & & & & $\begin{array}{l}.086 \\
(.082)\end{array}$ \\
\hline Migrant children in migrant schools ( $\leq 4$ years) & & & & & & $\begin{array}{l}-.306^{* *} \\
(.102)\end{array}$ \\
\hline Migrant children in migrant schools ( $\geq 5$ years) & & & & & & $\begin{array}{c}-.232 * \\
(.106)\end{array}$ \\
\hline Male & $\begin{array}{l}-.299 * * * \\
(.050)\end{array}$ & $\begin{array}{l}-.285 * * * \\
(.049)\end{array}$ & $\begin{array}{l}-.274 * * * \\
(.049)\end{array}$ & $\begin{array}{l}-.263 * * * \\
(.049)\end{array}$ & $\begin{array}{l}-.311 * * * \\
(.089)\end{array}$ & $\begin{array}{l}-.237 * * * \\
(.052)\end{array}$ \\
\hline 5th grade (ref. 3rd grade) & $\begin{array}{l}.351 * * * \\
(.050)\end{array}$ & $\begin{array}{l}.352 * * * \\
(.049)\end{array}$ & $\begin{array}{l}.347 * * * \\
(.048)\end{array}$ & $\begin{array}{l}.347 * * * \\
(.050)\end{array}$ & $\begin{array}{l}.347 * * * \\
(.050)\end{array}$ & $\begin{array}{l}.334^{* * * *} \\
(.054)\end{array}$ \\
\hline Having siblings & $\begin{array}{c}-.092 \\
(.053)\end{array}$ & $\begin{array}{c}-.033 \\
(.053)\end{array}$ & $\begin{array}{c}-.021 \\
(.053)\end{array}$ & $\begin{array}{c}-.026 \\
(.054)\end{array}$ & $\begin{array}{c}-.023 \\
(.055)\end{array}$ & $\begin{array}{c}-.042 \\
(.058)\end{array}$ \\
\hline Not living with both parents & & $\begin{array}{c}-.191 * \\
(.092)\end{array}$ & $\begin{array}{c}-.191 * \\
(.091)\end{array}$ & $\begin{array}{c}-.196^{*} \\
(.093)\end{array}$ & $\begin{array}{c}-.194 * \\
(.093)\end{array}$ & $\begin{array}{c}-.159 \\
(.098)\end{array}$ \\
\hline
\end{tabular}


TABLE 3 (Continued)

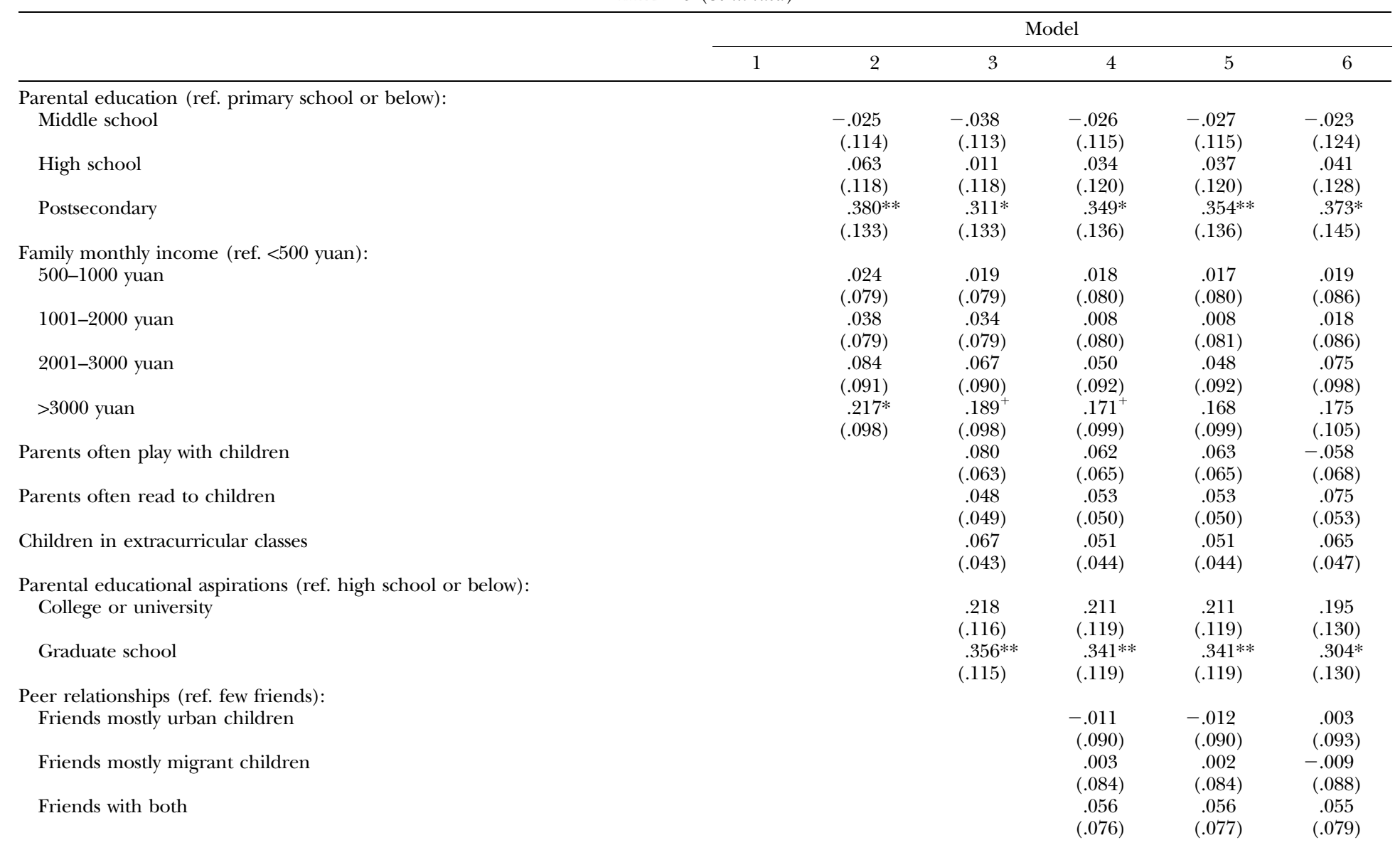




\section{Having been looked down on}

Neighborhood conditions (ref. mostly urban residents or some migrants):

Mostly migrants

Wave 3 (ref. wave 2)

Lagged test score

Constant

Migrant children in migrant schools

(Ref. migrant children in public schools)

Migrant children in migrant schools, * male

(Ref. migrant children in public schools $\leq 4$ years)

Migrant children in public schools ( $\geq 5$ years)

\begin{tabular}{|c|c|c|c|c|c|}
\hline & & & $\begin{array}{r}-.059 \\
(.051)\end{array}$ & $\begin{array}{c}-.059 \\
(.051)\end{array}$ & $\begin{array}{c}-.051 \\
(.054)\end{array}$ \\
\hline & & & $\begin{array}{c}.002 \\
(.052)\end{array}$ & $\begin{array}{c}.001 \\
(.052)\end{array}$ & $\begin{array}{c}.007 \\
(.056)\end{array}$ \\
\hline $\begin{array}{c}-.031 \\
(.041)\end{array}$ & $\begin{array}{c}-.034 \\
(.041)\end{array}$ & $\begin{array}{c}-.041 \\
(.042)\end{array}$ & $\begin{array}{r}-.100 \\
(.052)\end{array}$ & $\begin{array}{r}-.101 \\
(.052)\end{array}$ & $\begin{array}{r}-.064 \\
(.057)\end{array}$ \\
\hline $.142 * * *$ & $.124 * * *$ & $.112^{* * *}$ & $.086^{* * * *}$ & $.089 * * *$ & $.066^{*}$ \\
\hline$(.025)$ & $(.025)$ & $(.025)$ & $(.026)$ & $(.025)$ & $(.027)$ \\
\hline $.327 * * *$ & .002 & -.222 & -.238 & -.217 & -.288 \\
\hline$(.062)$ & $(.141)$ & $(.183)$ & $(.200)$ & $(.203)$ & $(.215)$ \\
\hline $\begin{array}{c}-.461 * * * \\
(.060)\end{array}$ & $\begin{array}{c}-.409 * * * \\
(.061)\end{array}$ & $\begin{array}{c}-.380 * * * \\
(.061)\end{array}$ & $\begin{array}{c}-.370 * * * \\
(.063)\end{array}$ & $\begin{array}{c}-.357 * * * \\
(.090)\end{array}$ & \\
\hline & & & & $\begin{array}{c}-.022 \\
(.119)\end{array}$ & \\
\hline & & & & & -.018 \\
\hline & & & & & $(.087)$ \\
\hline & & & & & $-.410 * * *$ \\
\hline & & & & & $(.102)$ \\
\hline & & & & & $\begin{array}{c}-.336^{* * *} \\
(.105)\end{array}$ \\
\hline
\end{tabular}

NOTE-Standard errors are in parentheses. See the note in table 2 for additional information. Ref. $=$ reference.

$+P<.10$.
$* P<.05$

** $P<.01$.

$* * *<<.001$ 
TABLE 4

Random Effect Models Predicting Loneliness, 2006-7 $(N=872)$

\begin{tabular}{|c|c|c|c|c|c|c|}
\hline & \multicolumn{6}{|c|}{ Model } \\
\hline & 1 & 2 & 3 & 4 & 5 & 6 \\
\hline \multicolumn{7}{|l|}{ Migration and school status (ref. urban children): } \\
\hline Migrant children in public schools & $\begin{array}{c}.044 \\
(.049)\end{array}$ & $\begin{array}{c}-.023 \\
(.055)\end{array}$ & $\begin{array}{r}-.020 \\
(.054)\end{array}$ & $\begin{array}{c}-.055 \\
(.053)\end{array}$ & $\begin{array}{c}-.016 \\
(.070)\end{array}$ & \\
\hline Migrant children in migrant schools & $\begin{array}{l}.337 * * * \\
(.054)\end{array}$ & $\begin{array}{l}.242 * * * \\
(.063)\end{array}$ & $\begin{array}{l}.217 * * * \\
(.061)\end{array}$ & $\begin{array}{l}.139 * \\
(.062)\end{array}$ & $\begin{array}{l}.177^{*} \\
(.078)\end{array}$ & \\
\hline \multicolumn{7}{|l|}{ Interaction by gender: } \\
\hline Migrant children in public schools, ${ }^{*}$ male & & & & & $\begin{array}{c}-.076 \\
(.087)\end{array}$ & \\
\hline Migrant children in migrant schools,* male & & & & & $\begin{array}{r}-.075 \\
(.094)\end{array}$ & \\
\hline \multicolumn{7}{|l|}{ By length (ref. urban children): } \\
\hline Migrant children in public schools ( $\leq 4$ years) & & & & & & $\begin{array}{l}-.043 \\
(.068)\end{array}$ \\
\hline Migrant children in public schools ( $\geq 5$ years) & & & & & & $\begin{array}{r}-.087 \\
(.057)\end{array}$ \\
\hline Migrant children in migrant schools ( $\leq 4$ years) & & & & & & $\begin{array}{l}.188^{* *} \\
(.070)\end{array}$ \\
\hline Migrant children in migrant schools ( $\geq 5$ years) & & & & & & $\begin{array}{c}.086^{+} \\
(.045)\end{array}$ \\
\hline Male & $\begin{array}{l}.065^{+} \\
(.038)\end{array}$ & $\begin{array}{l}.063 \\
(.038)\end{array}$ & $\begin{array}{l}.048 \\
(.037)\end{array}$ & $\begin{array}{l}.037 \\
(.036)\end{array}$ & $\begin{array}{l}.127^{*} \\
(.063)\end{array}$ & $\begin{array}{l}.034 \\
(.037)\end{array}$ \\
\hline Age & $\begin{array}{r}-.006 \\
(.015)\end{array}$ & $\begin{array}{r}-.008 \\
(.015)\end{array}$ & $\begin{array}{r}-.010 \\
(.014)\end{array}$ & $\begin{array}{c}-.014 \\
(.014)\end{array}$ & $\begin{array}{c}-.014 \\
(.014)\end{array}$ & $\begin{array}{r}-.017 \\
(.015)\end{array}$ \\
\hline Having siblings & $\begin{array}{c}.059 \\
(.038)\end{array}$ & $\begin{array}{c}.037 \\
(.039)\end{array}$ & $\begin{array}{l}.016 \\
(.039)\end{array}$ & $\begin{array}{c}.028 \\
(.038)\end{array}$ & $\begin{array}{c}.024 \\
(.038)\end{array}$ & $\begin{array}{c}.031 \\
(.040)\end{array}$ \\
\hline Not living with both parents & & $\begin{array}{c}.038 \\
(.061)\end{array}$ & $\begin{array}{c}.039 \\
(.060)\end{array}$ & $\begin{array}{c}.033 \\
(.060)\end{array}$ & $\begin{array}{c}.032 \\
(.060)\end{array}$ & $\begin{array}{c}.001 \\
(.063)\end{array}$ \\
\hline
\end{tabular}


Parental education (ref. primary school or below):

Middle school

High school

Postsecondary

Family monthly income (ref. $<500$ yuan):

500-1000 yuan

1001-2000 yuan

2001-3000 yuan

$>3000$ yuan

Parents often play with children

Parents often read to children

Parental educational aspirations (ref. high school or below):

College or university

Graduate schoo

Peer relationships (ref. few friends)

Friends mostly urban children

Friends mostly migrant children

Friends with both

Having been looked down on

Neighborhood conditions (ref. mostly urban residents or some migrants) Mostly migrants

Wave 3 (ref. wave 2)

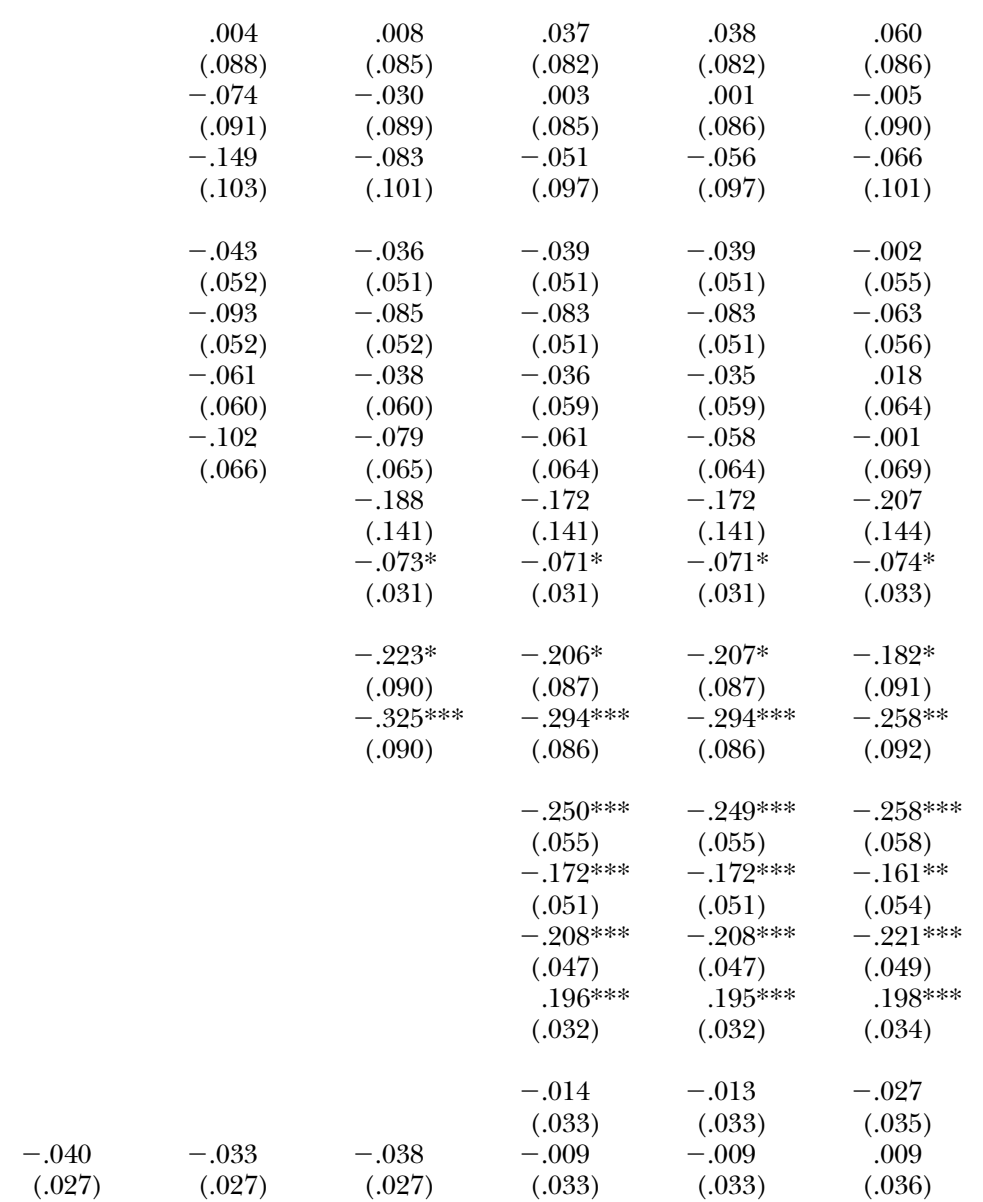




\begin{tabular}{|c|c|c|c|c|c|c|}
\hline & \multicolumn{6}{|c|}{ Model } \\
\hline & 1 & 2 & 3 & 4 & 5 & 6 \\
\hline Lagged loneliness scale & $\begin{array}{l}.406^{* * *} \\
(.024)\end{array}$ & $\begin{array}{l}.403 * * * \\
(.024)\end{array}$ & $\begin{array}{l}.379 * * * \\
(.024)\end{array}$ & $\begin{array}{l}.352 * * * \\
(.025)\end{array}$ & $\begin{array}{l}.351 * * * \\
(.025)\end{array}$ & $\begin{array}{l}.359 * * * \\
(.027)\end{array}$ \\
\hline Constant & $\begin{array}{l}1.680^{* * * *} \\
(.144)\end{array}$ & $\begin{array}{l}1.887 * * * \\
(.177)\end{array}$ & $\begin{array}{l}2.026^{* * * *} \\
(.200)\end{array}$ & $\begin{array}{l}2.146^{* * * *} \\
(.199)\end{array}$ & $\begin{array}{l}2.123^{* * * *} \\
(.200)\end{array}$ & $\begin{array}{l}2.110^{* * * *} \\
(.210)\end{array}$ \\
\hline $\begin{array}{l}\text { Migrant children in migrant schools } \\
\text { (Ref. migrant children in public schools) } \\
\text { Migrant children in migrant schools, }{ }^{*} \text { male }\end{array}$ & $\begin{array}{l}.292 * * * \\
(.046)\end{array}$ & $\begin{array}{l}.265^{* * * *} \\
(.047)\end{array}$ & $\begin{array}{l}.238 * * * \\
(.046)\end{array}$ & $\begin{array}{l}.195 * * * \\
(.045)\end{array}$ & $\begin{array}{l}.193 * * \\
(.065) \\
.001 \\
(.086)\end{array}$ & \\
\hline $\begin{array}{l}\text { (Ref. migrant children in public schools } \leq 4 \text { years) } \\
\text { Migrant children in public schools ( } \geq 5 \text { years) }\end{array}$ & & & & & & $\begin{array}{c}-.044 \\
(.057)\end{array}$ \\
\hline Migrant children in migrant schools ( $\leq 4$ years) & & & & & & $\begin{array}{l}.231 * * * \\
(.069)\end{array}$ \\
\hline Migrant children in migrant schools ( $\geq 5$ years) & & & & & & $\begin{array}{l}.129^{+} \\
(.070)\end{array}$ \\
\hline
\end{tabular}

NoтE.-Standard errors are in parentheses. See the note in table 2 for additional information. Ref. $=$ reference

$+P<.10$.
+

* $P<.05$.

** $P<.01$ 
negative social experiences facing migrant children also contribute to their greater sense of loneliness. Yet even after adjusting for all these factors, the substantial psychological costs for children in migrant schools held strong.

By contrast, we find no significant difference between migrant children in public schools and urban children, net of the same set of factors. Although attending public schools presented potential risks for intergroup conflicts and discrimination toward migrant children, the vast resources and opportunities in these schools may offset the possible risks and may even offer psychological benefits relative to being segregated in migrant schools. This tendency was particularly true over time, as migrant children stayed longer in cities. They seemed to adapt to local life and therefore experienced improved psychological well-being (model 6). Whereas we acknowledge these improvements over time, we note that the feelings of loneliness and isolation did not completely fade away for migrant-school children.

As for other predictors, spending more time with parents reduced the sense of loneliness. Perceived discrimination and peer relationships were highly predictive of children's psychological health. Having more friends, especially when the friendship circle extended to urban children, significantly decreased the likelihood of feeling lonely. In contrast, perceived discrimination significantly increased children's psychological problems. Hostile experiences and a lack of peer support could give rise to social isolation that affects children's overall well-being.

\section{Conclusion}

Migration in China allows a comparative perspective on many questions related to migration and child development. The present study built on US perspectives of school segregation and segmented assimilation developed for examining immigrant and minority children. Our results have highlighted the negative role of school segregation as a mechanism for segmented assimilation in the context of Chinese internal migration. We were able to document this adverse consequence by examining the disparities across children of different migration and school status in two domains of well-beingacademic achievement and loneliness.

Results show substantial disparities between migrant children in migrant schools and urban children, as well as migrant children in public schools. These differences remain strong after adjusting for a wide range of background factors. Migrant children able to enter formal urban schools fared relatively well and reached parity with urban children in the two dimensions examined. In contrast, migrant children segregated into informal migrant schools performed worst among the three groups of children in both outcomes. They not only failed to assimilate with urban children but also lagged behind migrant children in public schools. These unfavorable outcomes are likely associated with difficulties that they face in their urban destinations, 
including being deprived of many privileges of urban children and being subject to prejudices and discrimination. Over time, with increased duration of stay in cities, migrant children in public schools rapidly moved upward, achieving similar outcomes as local children. Migrant children segregated in migrant schools, however, continued to be treated as outsiders and failed to measure up to urban children, and even to migrant children attending public schools.

These findings point to the similarities and differences in the assimilation process between migrant children in China and children of immigrants in the United States. In both settings, discrimination toward migrants and their children is persistent. In the United States, however, these experiences are not unique to children of immigrants. Rather, they are largely borne by many minority native-born children.

Such discrimination has gradually lost its potent influence in many spheres of immigrants' lives in the United States, however. For example, immigrant children have the same access to education as native children and do not face significant school segregation. Many of them take these opportunities to achieve upward assimilation, even for the groups predicted to be vulnerable to downward assimilation. What distinguishes China is that the strong institutional barriers against the rural-origin population have deliberately limited many migrant children's access to the mainstream education and their ability to achieve social and economic integration. Many Chinese migrant children have to resort to substandard and segregated migrant schools and endure many difficulties and prejudices that make them vulnerable to low achievement. In this respect, the segmented assimilation outcomes, especially the scenario of downward assimilation, may be more likely to materialize in China. School segregation tends to play a crucial role in the process, with those segregated in migrant schools failing to assimilate with native children and falling to the bottom of the urban hierarchy, while those in desegregated schools achieve upward assimilation, at least in the two dimensions of well-being examined here.

These results do not indicate that there is no challenge to migrant children in public schools, and we have insufficient information on other aspects of children's experiences. The results do seem to suggest, however, that attending the same schools as local children offers migrant children at least some opportunities for better educational resources and for minimizing misunderstanding and prejudice. School integration could lead to much more permeable boundaries and further social and economic integration. Children in migrant schools reported the highest level of perceived discrimination and unfavorable outcomes. This finding suggests that their reception in Beijing is chilly because of school segregation.

Several limitations of this study should be acknowledged. First, family background, parental behaviors, and children's previous well-being may select 
migrant children into different types of schools and predispose them to differential outcomes. Although we found consistently large disparities even after adjusting for this wide array of potential confounding factors, we cannot completely rule out this source of bias. Ideally, better estimates could be obtained from longitudinal fixed-effects models that help adjust for unobserved heterogeneity. This approach, however, is not feasible given our data because it requires substantial changes over time in migration status and school status. But for Chinese migrants and their children, changes in migration (i.e., hukou) status or schools within a relatively short period of time have proven extremely difficult. Hence, we further conducted two sensitivity analyses to evaluate the robustness of the results to potential bias and to different model specifications, first by excluding the lagged dependent variable and second by replacing this variable with the baseline well-being measure of the first survey wave. The results, which are shown in the appendix, are very similar. In addition, because the estimates of children's academic performance are more vulnerable to school selection bias than are those of psychological health, the finding that both dimensions show a large gap across groups strengthens our confidence that these disparities at least partially reflect the adverse role of school segregation. Moreover, it is reasonable to expect the public schools admitting migrant children to be different from those admitting only urban children. Previous research suggests that public schools with migrant children are average (Tao and Yang 2007). Such schools are not the most selective (key-point) schools, where admission is extremely competitive and "donation fees" are excruciatingly high. The implication for our study is that migrant children in average public schools may do less well academically than urban children in the highly selective schools. In other words, while these migrant children achieve some degree of assimilation, they are not reaching the top of the academic hierarchy. However, our main conclusion of differential assimilation outcomes for different types of migrant children would not change. Rather, we suggest that the level of assimilation may be lower when taking into account urban children in the best public schools (who are not necessarily of interest for the purpose of this study because they are a highly selected group unrepresentative of typical urban children).

We also note that our data are restricted to Beijing, but it should be noted that Beijing represents an important case study, as it is a primary migration destination that affects a large number of migrant children and that carries considerable similarities to other large Chinese cities with a high concentration of migrants. Additionally, the sampling procedure yields a probability sample up to the class level but does not provide a strict probability sample of children. This limitation may introduce potential bias that circumscribes the interpretation of the findings. Hence, generalization beyond the study 
sample should be cautioned. Better data that provide a representative sample and richer information on migrant children are greatly needed.

As the migration continues in China, the number of migrant children will continue to rise. The need to improve their living conditions is urgent as their well-being is closely tied to their later socioeconomic outcomes as well as China's future social and economic development. In recent years, a series of promising policies for further enhancement of the education of migrant children has been enacted. For example, in 2008, the Beijing Municipal Education Commission formally introduced a school enrollment policy stating that migrant children in Beijing can receive free compulsory education in a nearby school, just like students with a Beijing household registration, without having to sit for an exam. However, as has been the case with many previous policies, these new policies are often stymied at the local level. To enroll children in public schools, many migrant families are still required to pay "donations" and to present numerous documents (e.g., temporary registration certificates, labor contracts, rental agreements) that are impossible for many families to provide. As a result, as recently as mid-2011, many migrant children in Beijing still attend migrant schools. Interviews with migrant parents echo these difficulties deterring them from sending their children to public schools (authors' fieldwork interviews in Beijing, May 2011).

Our study by no means questions the value of migrant schools. After all, these schools educate millions of migrant children in need. They may continue to play an important role because it may not be feasible to admit all migrant children to urban schools within a short time frame. That being said, measures should be taken to improve the capacity of existing migrant schools, ensuring that these schools are properly funded and gradually including them in the city's education planning. Some city governments have recently begun to take over relatively high-quality migrant schools and closed a number of poorly performing schools. Schools to be closed would transfer their students to other nearby public or migrant schools that have enough places. More importantly, measures should be taken to reform public schools, for example, by enforcing the regulations that eliminate substantial fees and exams for migrant children, by allocating quota for these schools to enroll migrant children, and by renovating low-enrollment public schools to maximize their capacity to admit migrant children.

This study's results provide some evidence of how experiences of discrimination, peer relationships, and the neighborhood environment are associated with migrant children's academic and psychological development. One implication is that, in addition to providing migrant children with highquality education, it would be fruitful to implement social programs that bolster migrant children's sense of belonging and raise urbanites' acceptance of migrants. These programs could include community- or school-based ac- 
tivities that provide opportunities for interaction between migrant and urban children, such as sport games and arts and crafts. With the right education and integration policies, there are reasons to believe that migrant children would thrive, as the sample of migrant children in public schools has indicated. These migrant children could further act as the ideal rural-urban bridge to set off a healthier urbanization process in China.

\section{Appendix}

TABLE A1

Sensitivity Analysis of Academic Performance and Psychological Well-Being, 20o6-7 $(N=872)$

\begin{tabular}{|c|c|c|c|c|}
\hline \multirow[b]{2}{*}{ Characteristic } & \multicolumn{2}{|c|}{$\begin{array}{l}\text { Analysis 1: Without } \\
\text { Lagged Outcome }\end{array}$} & \multicolumn{2}{|c|}{$\begin{array}{c}\text { Analysis 2: With Wave } 1 \\
\text { Lagged Outcome }\end{array}$} \\
\hline & Model 1 & Model 4 & Model 1 & Model 4 \\
\hline \multicolumn{5}{|l|}{ Math: } \\
\hline Migrant children in public schools & $\begin{array}{r}-.158 \\
(.087)\end{array}$ & $\begin{array}{l}.086 \\
(.081)\end{array}$ & $\begin{array}{r}-.095 \\
(.069)\end{array}$ & $\begin{array}{l}.124 \\
(.081)\end{array}$ \\
\hline Migrant children in migrant schools & $\begin{array}{c}-.232^{*} \\
(.103)\end{array}$ & $\begin{array}{l}.169 \\
(.107)\end{array}$ & $\begin{array}{r}-.152^{+} \\
(.079)\end{array}$ & $\begin{array}{l}.145 \\
(.098)\end{array}$ \\
\hline \multicolumn{5}{|l|}{ Language: } \\
\hline Migrant children in public schools & $\begin{array}{r}-.163 * \\
(.073)\end{array}$ & $\begin{array}{l}.069 \\
(.079)\end{array}$ & $\begin{array}{c}-.120 * \\
(.058)\end{array}$ & $\begin{array}{l}.038 \\
(.069)\end{array}$ \\
\hline Migrant children in migrant schools & $\begin{array}{l}-.673^{* * *} \\
(.081)\end{array}$ & $\begin{array}{l}-.382 * * * \\
(.095)\end{array}$ & $\begin{array}{l}-.507 * * * \\
(.065)\end{array}$ & $\begin{array}{l}-.337 * * * \\
(.082)\end{array}$ \\
\hline \multicolumn{5}{|l|}{ Loneliness: } \\
\hline Migrant children in public schools & $\begin{array}{l}.064 \\
(.074)\end{array}$ & $\begin{array}{l}.062 \\
(.059)\end{array}$ & $\begin{array}{l}.026 \\
(.043)\end{array}$ & $\begin{array}{r}-.048 \\
(.042)\end{array}$ \\
\hline Migrant children in migrant schools & $\begin{array}{l}.392 * * * \\
(.079)\end{array}$ & $\begin{array}{l}.147^{*} \\
(.068)\end{array}$ & $\begin{array}{l}.279 * * * \\
(.047)\end{array}$ & $\begin{array}{l}.106^{*} \\
(.053)\end{array}$ \\
\hline
\end{tabular}

NotE.-Models 1 and 4 correspond to the respective models in tables 2-4. The reference category is urban children. Analysis 1 is formulated as $y_{i j}=\beta_{0}+\zeta_{j}+\beta_{1} X_{(i-1) j}+\varepsilon_{i j}$. Analysis 2 is formulated as $y_{i j}=\beta_{0}+\zeta_{j}+\beta_{1} X_{(i-1) j}+\beta_{2} y_{1 j}+\varepsilon_{i j}$. $+P<.10$.

$* P<.05$.

$* * * P<.001$

\section{References}

Alba, Richard, and Victor Nee. 2003. Remaking the American Mainstream: Assimilation and Contemporary Immigration. Cambridge, MA: Harvard University Press.

$\rightarrow$ Aneshensel, Carol S. 1992. "Social Stress: Theory and Research." Annual Review of Sociology 18:15-38.

$\rightarrow$ Asher, Steven R., Shelley Hymel, and Peter D. Renshaw. 1984. "Loneliness in Children." Child Development 55 (4): 1457-64.

$\rightarrow$ Brockerhoff, Martin. 1994. "The Impact of Rural-Urban Migration on Child Survival." Health Transition Review: The Cultural, Social, and Behavioral Determinants of Health 4 (2): 127-49.

Capps, Randolph, Michael Fix, and Jane Reardon-Anderson. 2003. "Children of Immigrants Show Slight Reductions in Poverty, Hardship.” Snapshots of America's Families, Report 13. Washington, DC: Urban Institute. 
$\rightarrow$ Chan, Kam Wing, and Li Zhang. 1999. "The Hukou System and Rural-Urban Migration in China: Processes and Changes." China Quarterly 160:818-55.

$\rightarrow$ Chen, Xinyin, Mowei Liu, and Dan Li. 2000. "Parental Warmth, Control, and Indulgence and Their Relations to Adjustment in Chinese Children: A Longitudinal Study." Journal of Family Psychology 14 (3): 401-19.

China Youth Research Centre (CYRC ). 2006. China's Children and Juveniles Statistical Handbook. Beijing: Science Press.

Darling-Hammond, Linda, and Laura Post. 2000. "Inequality in Teaching and Schooling: Supporting High-Quality Teaching and Leadership in Low-Income Schools." In Disparities in Teacher Quality among Early Career Special Education in High- and Low-Poverty Districts, ed. R. D. Kahlenberg. New York: Century Foundation Press.

Du, Zhong. 2006. "Who Abandons Migrant Schools?” Law and Life 17 (17): 2-24.

Duan, Chengrong, and Hao Zhou. 2001. "An Analysis on the Situation of Floating Children and Juveniles in the City of Beijing." Population and Economics 124:511.

Ellen, Ingrid G., Katherine O'Regan, Amy E. Schwartz, Leanna Stiefel, Derek Neal, and Thomas Nechyba. 2002. "Immigrant Children and New York City Schools: Segregation and Its Consequences." Brooking-Wharton Papers on Urban Affairs (2002): 183-214.

$\rightarrow$ Farley, Reynolds, and Richard Alba. 2002. "The New Second Generation in the United States." International Migration Review 36 (3): 669-701.

Fernandez-Kelly, Patricia, and Sara Curran. 2001. "Nicaraguans: Voices Lost, Voices Found." In Ethnicities: Children of Immigrants in America, ed. R. G. Rumbaut and A. Portes. Berkeley: University of California Press.

$\rightarrow$ Fleisher, Belton M., and Dennis T. Yang. 2003. "Labor Law and Regulations in China." China Economic Review 14 (4): 426-33.

Foner, Nancy. 2005. In a New Land: A Comparative View of Immigration. New York: New York University Press.

Guo, Fei. 2002. "School Attendance of Migrant Children in Beijing, China: A Multivariate Analysis." Asian and Pacific Migration Journal 11 (3): 357-74.

$\rightarrow$ Hao, Lingxin, and Suet-Ling Pong. 2008. "The Role of Schools in the Upward Mobility of Disadvantaged Immigrant Children." Annals of the American Academy of Political and Social Sciences 620:62-89.

$\rightarrow$ Kasinitz, Philip, John Mollenkopf, and Mary C. Waters. 2002. "Becoming American/ Becoming New Yorkers: Immigrant Incorporation in a Majority Minority City." International Migration Review 36 (4): 1020-36.

$\rightarrow$ Kwong, Julia. 2004. "Educating Migrant Children: Negotiations between the State and Civil Society." China Quarterly 180:1073-88.

$\rightarrow$ Laursen, Brett. 1995. "Conflict and Social Interaction in Adolescent Relationships." Journal of Research on Adolescence 5 (1): 55-70.

Li, Limei, and Si-ming Li. 2010. "The Impact of Variations in Urban Registration within Cities." In One Country, Two Societies, ed. M. Whyte. Cambridge, MA: Harvard University Press.

$\rightarrow$ Liang, Zai, and Yiu P. Chen. 2007. "The Educational Consequences of Migration for Children in China." Social Science Research 36 (1): 28-47.

Lin, Zeng, and Yin Weng. 2004. "Investigation on the Psychological Well-Being of 
Junior Middle School Student in Migrant Schools." Chinese Mental Health Journal 18:116-21.

Lu, Yao. 2007. "Educational Status of Temporary Migrant Children in China: Determinants and Regional Variations." Asian and Pacific Migration Journal 16 (1): $29-55$.

$\rightarrow$ McClearn, Gerald E., Boo Johansson, Stig Berg, Nancy L. Pedersen, Frank Ahern, Stephen A. Petrill, and Robert Plomin. 1997. "Substantial Genetic Influence on Cognitive Abilities in Twins 80 or More Years Old." Science 276 (5318): 1560-63.

$\rightarrow$ Meng, Xin, and Junsen Zhang. 2001. "The Two-Tier Labor Market in Urban China: Occupational Segregation and Wage Differentials between Urban Residents and Rural Migrants in Shanghai." Journal of Comparative Economics 29 (3): 485-504.

National Bureau of Statistics (NBS). 2011. Demographic Statistics from the 2010 Census. Beijing: China Statistics Press.

$\rightarrow$ Plomin, Robert, David W. Fulker, Robin Corley, and John C. DeFries. 1997. "Nature, Nurture, and Cognitive Development from 1 to 16 Years: A Parent-Offspring Adoption Study." Psychological Science 8 (6): 442-47.

$\rightarrow$ Portes, Alejandro, and Min Zhou. 1993. "The New Second Generation: Segmented Assimilation and Its Variants." Annals of the American Academy of Political and Social Science 530 (1): 74-96.

$\rightarrow$ Postmes, Tom, and Nyla R. Branscombe. 2002. "Influence of Long-Term Racial Environment Composition on Subjective Well-Being in African Americans." Journal of Personality and Social Psychology 83 (3): 735-51.

Raudenbush, Stephen W., and Anthony S. Bryk. 2002. Hierarchical Linear Models: Applications and Data Analysis Methods. Thousand Oaks, CA: Sage.

$\rightarrow$ Roberts, Kenneth D. 1997. "China's 'Tidal Wave' of Migrant Labor: What Can We Learn from Mexican Undocumented Migration to the United States?" International Migration Review 31 (2): 249-93.

Ruan, Danching. 2009. Migration and the Remaking of Shanghai. Beijing: Xuelin.

Rubin, Kenneth H., Robert J. Coplan, Julie C. Bowker, and Melissa Menzer. 2002. "Social Withdrawal and Shyness." In Blackwell Handbook of Childhood Social Development, ed. P. K. Smith and C. H. Hart. Oxford: Wiley.

$\rightarrow$ Rumberger, Russell W., and Gregory J. Palardy. 2005. "Does Segregation Still Matter? The Impact of Student Composition on Academic Achievement in High School." Teachers College Record 107 (9): 1,999-2,045.

Schofield, Janet W. 1995. "Review of Research on School Desegregation's Impact on Elementary and Secondary Students." In Handbook of Research on Multicultural Education, ed. J. A. Banks. New York: Macmillan.

Solinger, Dorothy J. 1999. Contesting Citizenship in Urban China: Peasant Migrants, the State, and the Logic of the Market. Berkeley: University of California Press.

Sun, Wanping. 2007. "Psychological Well-Being of Children of Migrant Workers from an Elementary School in Chong Qing." Chinese Journal of School Health 28: $68-76$.

Tao, Han, and Dong Yang. 2007. "Problems and Strategies concerning the Education of Migrant Children in Beijing." Jiangxi Educational Research 1:61-63.

Wang, Fang. 2009. "The Education of Migrant School-Age Children in Beijing." Working Paper, Chinese Academy of Social Sciences, Beijing.

$\rightarrow$ Wells, Amy S., and Robert L. Crain. 1994. "Perpetuation Theory and the Long- 
Term Effects of School Desegregation.” Review of Educational Research 64 (4): 53155.

$\rightarrow \mathrm{Wu}$, Xiaogang, and Donald J. Treiman. 2004. "The Household Registration System and Social Stratification in China: 1955-1996." Demography 41 (2): 363-84.

Xiao, Kun, and Bin Feng. 2008. "Psychological Health Problems Facing Migrant Children." Hebei Education Journal 3:18-19.

$\rightarrow$ Yang, Quanhe, and Fei Guo. 1996. "Occupational Attainments of the Rural to Urban Temporary Economic Migrants in China, 1985-1990.” International Migration Review 30 (3): 771-87.

$\rightarrow$ Zhang, Kevin H., and Shunfeng Song. 2003. "Rural-Urban Migration and Urbanization in China: Evidence from Time-Series and Cross-Section Analyses." China Economic Review 14 (4): 386-400.

Zhou, Hao. 2008. "A Study on Psychological Status of Migrant Children.” Population and Economics 6:7-14.

Zou, Hong, Zhiyong Qu, and Qiuling Zhang. 2005. "The Development and Needs of Migrant Children in Nine Chinese Cities.” Youth Studies 2005 (2): 1-7. 